\title{
Brazil and my life in Health Technology Assessment
}

\author{
O Brasil e minha vida na Avaliação de \\ Tecnologias em Saúde
}

\author{
Brasil y mi vida en la Evaluación de Tecnología \\ en Salud
}

David Banta 1

doi: 10.1590/0102-311X00055420

My father wanted me to be a physician (as a farmers' son, he was too poor to go to medical school, but that was his ambition for me). In medical school in North Carolina, USA, I had no introduction to public health or evaluation of medical interventions. My favorite professor was a cardiologist, so I intended to become an academic cardiologist 1,2. He said the only thing I remember up until then on either public health or evaluation, concerning a clinical trial of anticoagulants to prevent coronary artery disease. As a medical intern and resident, I also learned little of either public health or evaluation. However, I do remember that we were encouraged to experiment on patients. I particularly remember trying out a popular technology, "gastric freezing in bleeding peptic ulcer", which I remembered with regret later, when trials came out showing that the practice was useless and harmful 3.

A fellow trainee introduced me to the idea of disease prevention, which made great sense to me. The next year I went to the Centers for Disease Control and Prevention (CDC), in Atlanta, USA, for two years. In the second year, CDC was asked by the Peace Corps to organize a training program on schistosomiasis control for projects in Brazil. I visited Brazil for a month to understand the problem and possible solutions. In addition to Rio de Janeiro, I visited Salvador (Bahia State), Belo Horizonte (Minas Gerais State), and Petrópolis (Rio de Janeiro State).

Then, I went to public health school at Harvard University for two years to study for a master's degree in public health, in the Department of Tropical Public Health. But my courses convinced me that public health administration was a better subject for me. In the second year at Harvard, working for another master's degree, I studied sociology and sociology research methods, as well as health service administration 4. At the end of that time, in 1969, I was invited to join the Mount Sinai Department of community medicine in New York (called social medicine or preventive medicine in some schools).

My main colleague in that department was an Argentine physician, Dr. Sammy Bosch. Sammy had been a clinician, but had visited Kaiser health centers in California and Oregon and then developed a prepaid group practice in Buenos Aires. With President Nixon's health maintenance organization policy, we attempted to develop a new prepaid practice in New York (we weren't successful). We also taught subjects related to prepaid practice to medical students and others 5 .

Sammy Bosch was a Milbank Faculty Fellow. He nominated me an Associate Fellow. We developed a proposal that involved international visits and studies concerning health care organizations.
1 Independent researcher.

Correspondence D. Banta Utrechtsedwarsstraat 170 Amsterdam, N-H - 1017WP, Netherlands. davidbanta@me.com 
I was accepted. My first trip was to Colombia, Peru, Chile, Argentina and Brazil. I had learned some Spanish in New York with Sammy's help, and improved it on this trip. I learned a great deal about health care delivery on this trip ${ }^{6}$. I also learned a great deal about politics. Three of the Milbank Fellows were from the State of São Paulo, and I visited them during a trip in 1972. I saw them subsequently in meetings of the Fellows. Dr. Jose Teruel became a close friend and was later instrumental in having me appointed as Deputy Director of the Pan American Health Organization (PAHO).

After 5 years in New York, I was almost entirely involved in medical education. That had not been my ambition! My chairman understood my frustration and nominated me for the new Robert Wood Johnson Health Policy Fellowship. I spent a year in Washington DC working in the U.S. Congress on health issues 7 .

During that year, 1974, I attended the annual meeting of the Institute of Medicine, in which Dr. Archie Cochrane was the featured speaker. Cochrane had been invited because of his 1972 book Effectiveness and Efficiency ${ }^{8}$. Cochrane argued that much of the medical practice was ineffective or unproven and should be subject to randomized controlled clinical trials. He developed the case whose resulting evidence would transform [medical] practice, administration, and policy. I was fascinated and challenged by his thesis, which I found entirely convincing.

In 1972, the Congress had developed its Office of Technology Assessment (OTA) due to general concerns about technology. It had not initially developed a health program. The Chairman of the Congressional Board in 1974 was Senator Edward Kennedy. I knew him a bit and I knew his health staff well. A new staff member of OTA was asked to develop a health program. Kennedy's staff member had also heard the Cochrane speech. I can speculate that he was instrumental in developing the letter from Senators Kennedy and Javits that asked OTA "to examine current Federal policies and existing medical practices to determine whether a reasonable amount of justification should be provided before costly new medical technologies and procedures are put into general practice" 9 (p. vii).

I was asked if I was interested in joining OTA at the end of my Fellowship. I inquired what kind of person OTA was looking for. The answer was "I need a physician, well trained, with knowledge of research, some knowledge of medical technology, especially drugs and medical devices, and knowledge of health policy". I said: "nobody knows all that. But I know something about it". I accepted the offer with the proviso that I could be in charge of the subject described in the Kennedy and Javits letter. I began in September 1975.

I started to develop the basis for trying to answer the Kennedy/Javits letter when a young man came into my office looking for a job. He told me he had a PhD from Harvard in neurobiology and was about to start a post-doctoral fellowship. However, he felt he needed to know something about Washington and policy-making and wanted to spend six months. I offered him a job, and he became a great colleague! (Dr. Josh Sanes has been Professor of Neurobiology at Harvard University for years and is now retiring).

OTA functioned by having reports written by OTA staff, with input from outside experts and advisory committees. We had great freedom in choosing advisors and members of advisory committees. The health program appointed a multidisciplinary advisory committee of distinguished experts with knowledge of health policy chaired by Dr. Frederick Robbins, Nobel Laureate for his work on viral culturing. This committee was very helpful in the early stages of the program with advice and input.

Josh and I wrote the first report on medical technology and assessment, published in August 19769 (Figure 1). This report examined the general literature of technology assessment and attempted to relate health technology to it. I think it was a good report; however, it never gained much attention.

I intended to follow that with a report on assessing efficacy and safety. However, I learned about the new computed tomography (CT) scanner from our advisory committee. I told a staff member of the Senate Finance Committee about this new expensive technology and he asked us to look into it. Josh and I wrote a "Memorandum" for the Committee, which they praised highly. Then, we decided to expand the document into a report. The main conclusion of our report was that CT was an exciting but expensive medical advance that was diffusing rapidly without sufficient evaluation. As soon as we had a draft, in late 1976, we sent it to outside reviewers. It became an instant hit and spread around the world, literally. Suddenly, I was famous in policy circles worldwide. I had requests for copies of the draft from Japan, Australia, England, Mexico, and many other countries. 


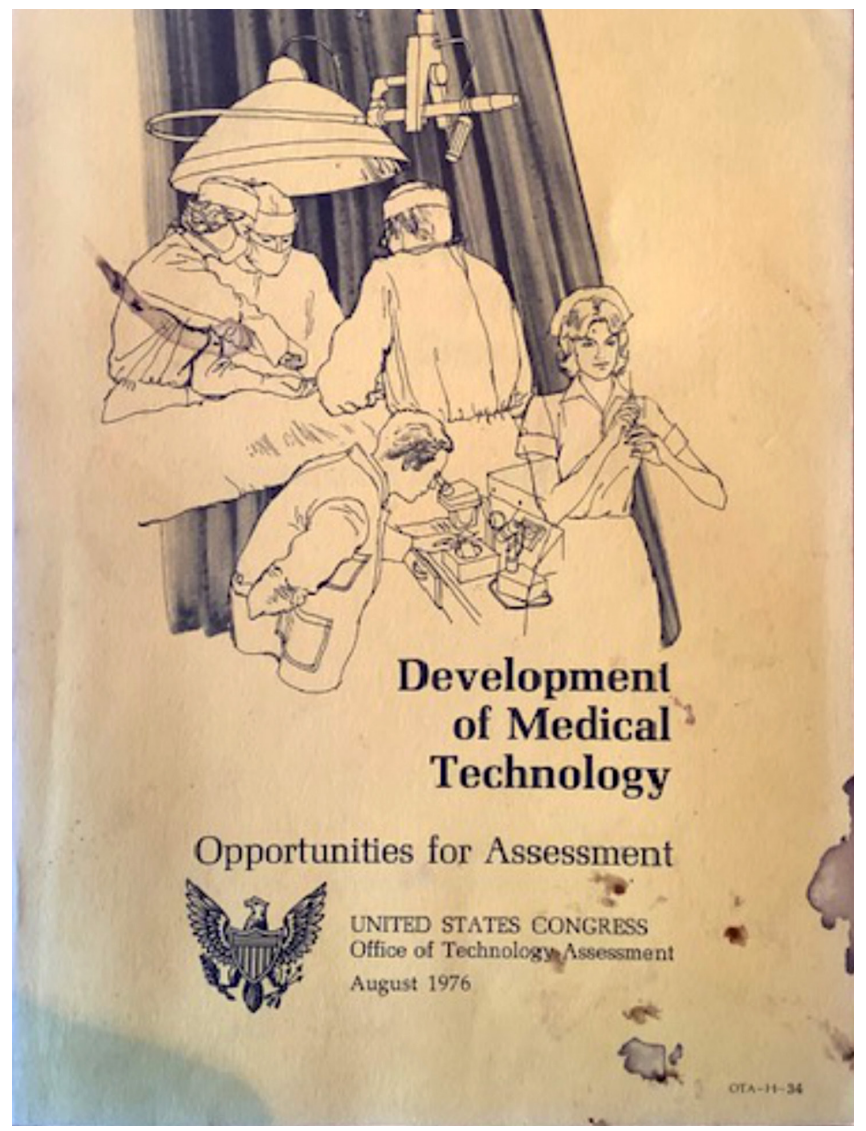

OTA had many administrative problems in these early days. I had great frustration having my work accepted and published. The program manager asked for draft after draft without specific criticisms, apparently because he was insecure. Because of this and other problems, I left OTA. The Director of OTA was removed by the Congressional Board about this time, probably in part due to administrative problems. The new director asked me to return as the head of the health program, which I did 9 months after leaving.

From 1977 to 1983, under my direction, the health program published a large number of reports. However, those I am proudest of and am largely responsible for are the "CT report", published in 1978 10, and the "efficacy and safety report" also published in 1978 11. These reports indicated how much a better evaluation was needed, and also discussed the methods of evaluation. This was the beginning of Health Technology Assessment (HTA), which we then called "medical technology assessment".

In 1981, three of us in OTA wrote the first book on HTA, published by Springer in New York. I am proud that Senator Kennedy wrote an eloquent foreword for this book 12 .

What is missing in this story is the contributions of many people who assisted in this early work. The entire staff of the health program was superb, young, well-trained and highly motivated. We had the best advisors. I don't remember any person we approached to serve on an advisory committee that said "no". We hired the best people we could find to do contracts on specific subjects for us. It could not have been a better education. 
My next contact with Brazil was in a Latin American meeting on HTA, organized by PAHO in Brasília in 1980. I met Dr. Hesio Cordeiro at that meeting and we became good friends. I saw him many times in the subsequent years.

I left OTA in 1983 to go to PAHO (Figure 2). The Congress is almost entirely focused on the USA with a time frame seldom beyond two years in the future. I found those years increasingly frustrating. I wanted to work internationally. I visited Brazil twice as Deputy Director of PAHO, with opportunities to discuss HTA. However, the Director of PAHO failed to effectively encourage HTA in Latin America, and I was offered a two-year job in HTA in the Netherlands, which I accepted. This position opened up work opportunities in the rest of the world.

However, I did not forget my interest in Brazil. I wrote several articles concerning Latin America, Brazil, health care, and HTA 13,14,15. In 1985, I met Dr. Leticia Krauss-Silva, who was working on her

\section{Figure 2}

I meet with Senator Kennedy, Chairman of the Office of Technology Assessment (OTA) board, at the time of leaving OTA in 1983.

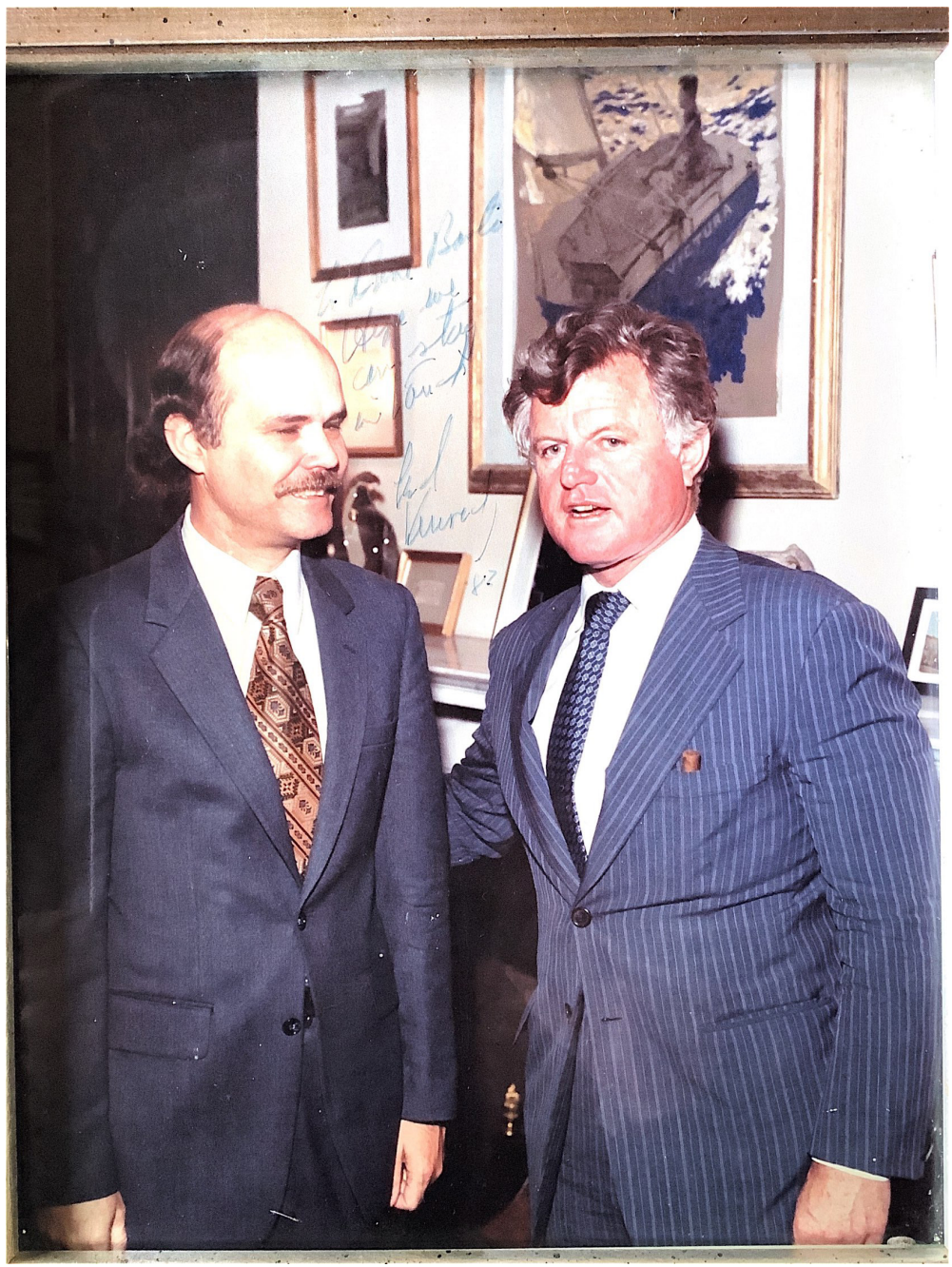

Note: the photo was taken on June 16, 1983 in the office of Senator Edward Kennedy in the Senate Office Building, Congress of the United States, Washington DC, USA. The photo is signed, "David Banta, Let's keep in touch. Edward Kennedy". 
$\mathrm{PhD}$ at Oxford University in the UK. In 1992, I was invited to be External Examiner on Leticia's PhD thesis, which was on cost effectiveness of neonatal intensive care in Rio de Janeiro. Subsequently, Leticia invited me several times in the 1990s to come to Brazil to teach and consult on HTA. During one of these seminars, we went to Brasília and discussed the necessity of a national HTA program in Brazil under the Ministry of Health (several staff from the Ministry participated). During these visits, I saw an increasing interest in HTA and a growing expertise in evaluation. Dr. Claudia Travassos participated in one seminar and we also became good friends. Later I participated in a conference on HTA in Porto Alegre, about 2010, working with Dr. Paulo Picon. Paulo and I then wrote a paper on the clinical guidelines program for expensive drugs in Brazil 16.

I had no direct part in the development of the national HTA program in Brazil. As those interested know, DECIT (the Brazilian National Department of Science and Technology) commenced an HTA program in 2008 and there were related developments in national health technology policy. I described these developments in a paper co-authored by Dr. Rosemary Almeida ${ }^{17}$. Although I take no credit for this fact, an evaluation of selected HTA programs around the world, which I participated in, found the Brazilian program equivalent in quality to those in other countries, including Canada and European countries, based on its formal publications and descriptions on the website 18 .

In summary, my life has led me to HTA, and to love Brazil. I am mostly retired, but in 2015 I gave a keynote speech to the ISQUA Meeting in Rio on HTA, invited by Dr. Jose Noronha. I continue to visit Brazil about once a year, since I have good friends and colleagues in the country. I could write another paper on how Brazil has changed my life!

\section{Additional information}

ORCID: David Banta (0000-0003-4882-7317).

\section{Acknowledgment}

The author wishes to acknowledge Leticia KraussSilva who commented on an earlier draft of the paper.

\section{References}

1. Banta HD, Estes Jr. EH. Electrocardiographic and vectorcardiographic findings in patients with idiopathic myocardial hypertrophy. Am J Cardiol 1964; 14:218-25.

2. Banta HD, Greenfield JC, Estes Jr. EH. Left axis deviation. Am J Cardiol 1964; 14:330-8.

3. Fineberg HV. Gastric freezing: a study of diffusion of a medical innovation. In: Committe on Technology and Health Care, editor. Medical technology and the health care system. Washington DC: National Academy of Science; 1979. p. 173-200.

4. Banta HD, Fox RC. Role strains of a health care team in a poverty community. Soc Sci Med 1972; 6:697-722.

5. Bosch SJ, Banta HD. Medical education in prepaid group practice. JAMA 1970; 212:2101-4.

6. Thacker S, Banta HD. National service in rural areas: the case of Colombia. Bull Pan Am Health Organ 1976; 10:156-62.

7. Banta HD, Bauman P. Health services research and health policy. J Community Health 1976; 2:121-32.

8. Cochrane AL. Effectiveness and efficiency: random reflections on health services. London: Nuffield Provincial Hospitals Trust; 1972.

9. Office of Technology Assessment, U.S. Congress. Development of medical technology: opportunities for assessment. Washington DC: U.S. Government Printing Office; 1976. 
10. Office of Technology Assessment, U.S. Congress. Policy implications of the computed tomography (CT) scanner. Washington DC: U.S. Government Printing Office; 1978.

11. Office of Technology Assessment, U.S. Congress. Assessing the efficacy and safety of medical technologies. Washington DC: U.S. Government Printing Office; 1978.

12. Kennedy EM. Foreword. In: Banta HD, Behney CF, Willems JS, editors. Toward rational technology in medicine. New York: Springer Publishing Company; 1981. p. vi-ix.

13. Banta HD. Applicaciones de la epidemiología en la evaluación de la tecnología médica. Buenos Aires: Organización Panamericana de la Salud/Organización Mundial de la Salud; 1984. p. 199-210. (Publication PNSP 84-47).

14. Coe G, Banta HD. Health care technology transfer in Latin America and the Caribbean. Int J Technol Assess Health Care 1992; 8:25567.
15. Banta HD. The transfer of medical technology in developing countries: the case of Brazil. In: Rutten FFH, Reiser SJ, editors. The economics of medical technology. Berlin: Springer-Verlag; 1988. p. 16-24.

16. Picon P, Beltrame A, Banta, D. National guidelines for high-cost drugs in Brazil: achievements and constraints of an innovative evidence-based public health policy. Int J Technol Assess Health Care 2013; 29:198-206.

17. Banta D, Almeida R. The development of health technology assessment in Brazil. Int J Technol Assess Health Care 2009; 25:255-9.

18. Oortwijn W, Broos P, Vondeling H, Banta D. Mapping of Health Technology Assessment in selected countries. Int J Technol Assess Health Care 2013; 29:424-34. 